\title{
モデリングから見る小説における助詞の経時変化
}

\section{Modeling Analysis of Diachronic Changes in Auxiliary Words in}

\section{Novels}

\author{
李広微 $1^{*}$, 金明哲 ${ }^{2}$ \\ Guangwei $\mathrm{LI}^{1^{*}}$, Mingzhe JIN ${ }^{2}$
}

1 同志社大学 文化情報学研究科

Graduate School of Culture and Information Science, Doshisha University

干610-0394 京都府京田辺市多々羅都谷1-3

E-mail: liguangwei7@126.com

2 同志社大学 文化情報学部

Faculty of Culture and Information Science, Doshisha University

干610-0394 京都府京田辺市多々羅都谷1-3

E-mail: mjin@doshisha.ac.jp

*連絡先著者 Corresponding Author

助詞は文章の表現特性・文体様式の特徵を把握するうえで重要な要素であり, その経時変化の 考察は, 言語及び文体の変遷過程の一端を明らかにすることにつながる. 本研究では, 百余年間に わたった近現代小説を分析対象とし，モデリングを通して助詞の経時変化を捉え，小説の言語表現 及び文体との関わりについて考察を試みた. 具体的には, 1910年から2014年に出版された小説のコ 一パスを作成し, 助詞の使用データ状況について計量分析を行った. 計量分析には, まず系統樹 分析を通して, 助詞の使用に明らかな変化が発生していることを確認したうえで, 主な変動要素を特 定するため, elastic net回帰分析を用いて, 助詞に関するモデルを作成し, モデル構築に大きく寄与 する助詞項目を抽出し, 分析を試みた. 観察された結果は言語学や文体学に関わる問題を考えるヒ ントになり得ることが示された。

Auxiliary words are key elements in observing expressive characteristics and stylistics of articles, and the study of diachronic changes in auxiliary words is helpful in understanding the process of language evolution and stylistic changes. In this study, we applied a statistical approach to investigate the diachronic variation in auxiliary words, and examined the correlation between these changes and stylistics. Our experiments were conducted on a diachronic corpus consisting of contemporary novels. The publication dates of these novels spanned from 1910 to 2014. First, through a phylogenetic tree 
analysis, it was confirmed that the use of auxiliary words changed significantly. Second, we conducted an elastic net regression, and extracted those particles that play important roles in model construction. The findings of this research point to concrete evidence for language change and offer a better understanding of the dynamicity of stylistic features in modern Japanese novels.

キーワード: 助詞, 経時変化, 系統樹, elastic net 回帰, ネットワーク分析

auxiliary word, diachronic change, phylogenetic tree, elastic net regression, network analysis

\section{1 はじめに}

日本語は，叙述すべき事柄を請け負う語 彙の一つひとつに助詞の形で添えて確め ながら先へ先へと進めていく表現方式を 取っている，という特徵を持つと言われる [1].このような構文的性格のため，日本語 文章の表現特性及びその変化を助詞から 窺い知ることができる。山口（1982）は， いくつかの助詞と助動詞の使い方を手が かりに，古代語の再現がもたらした文体効 果及び江戸文語文の書き手の尚古・擬古意 識を考究した [2]. 柳父（2004）は，名詞中 心の西洋式表現を倣って作られた「〜八」 構文が，どのように文の主語，句読点，文 末語, 漢字などに影響を与えているかを分 析し，近代の「翻訳的」文体の成立過程を 提示した [3]. これらの研究で共通するの は，時枝（1949）が強調した「沈潜の深さ， 凝視の鋭さ」 [4]によって, 一見何でもない 平凡な言語現象の中に存する「変」のいく つかを嗅ぎ出すところである. 見出された

「変」が一つひとつの点として繋がれば, 線が生まれ, 面が形づくられ, そして基盤 が形成された時，また何らかの新しい方向 性が見えてくると考えられる。しかし，面 に行くまで多数の「変」の点を見つけ出す ことが必要であり, 研究者の個人の感受力 だけでは限界がある。また, 数多くの変化
する点のなか, 文章の表現特性・文体様式 に重要な役割を果たしているものもあれ ば，それほどでないものもあるため，特徴 的な変化を見極めることが困難である.

近年ではコーパス言語分析の環境整備 に伴い，データの計量分析を通して言語変 化の傾向及び特徵を考察する研究が盛ん になってきている.コーパスに基づいた近 現代日本語の助詞についての先行研究は, 大まかに二種類に分けられる。一つ目は, 使用パターンの分類, 又は語法記述・意味 記述の精緻化を主な目的とする研究であ る [5] [6] [7]. この類の研究では, 助詞の文 法特性・機能に注目することが一つの特徵 である。二つ目は，異なるレジスターのテ キスト又は発話における助詞の使用実態 を比較する研究である。中西（2007）は， 日本語学習者と日本語母語話者の書きこ とば・話しことばにおけるとりたて助詞の 使用の違いを調査した [8]. 宮内 (2012) は, 12種類の接続助詞について分析を行い，こ れらが話し言葉的文体と書き言葉的な文 体，フォーマルな文体などの違いによって 使い分けられていると報告した [9]. 丸山 （2015）は格助詞について書籍，雑誌，新 聞, 白書, Yahoo ! ブログの六つの媒体に出 現した頻度を用いて比較を行った [10]. こ のように，カテゴリ別に集約した助詞の頻 度をもとに比較を行い, 分析対象の特徵を 
記述する研究が行われているが，いくつか の課題が残されている。第一に，「書籍」 や「雑誌」又は「書き言葉」などといった カテゴリの観点で分類しているが，そこに もさまざまな種類（若しくはジャンル）の テキストが集積されており，一様に一つの パターンに括ることに問題がないとは言 い切れない.この点は小林・小木曽 (2013) の研究に裏付けられている. 小林らが中古 和文の物語文学と日記文学における助詞・ 助動詞の使用傾向を調查した結果による と，ジャンルによって大きな差が見られる ことが分かった [11]. そのため，テキスト のジャンルに応じて細分化して考察する 必要があると考えられる，第二に，異なる カテゴリ間の比較はあったが，カテゴリ内 の経時的な変化を全体的に把握する分析 は少ない。

そこで本稿では，小説といったカテゴリ の通時コーパスを作成したうえで, 助詞の 使用変化にモデリング解析を導入し，その 変動状況を再現可能な形で捉え, 顕在化さ せる. それに基づいて, 特徴的な変動要素 を特定し, 言語学や文体学の研究に新視点 の発見に繋がるものを提示する.

\section{2 データ}

\section{1 コーパスの構築}

現在, 日本では小説などの文学作品を収 録した電子コーパスはいくつか公開され ている，その内，青空文庫は，著作権が消 滅した作品を中心に取り扱っている. 国立 国語研究所編『現代日本語書き言葉均衡コ 一パス』(BCCWJ)は, 書籍全般, 雑誌全般, 新聞, 白書, ブログ, ネット掲示板, 教科 書，法律などのジャンルにまたがって書き 言葉の資料を格納しているが，現時点では
その収録対象の刊行年代は, 最大 30 年間 （1976２005）であり，メインとなる書籍 の場合は，1986から2005年になっている. そのほか, 国立国語研究所が日本語史研究 の基礎資料として開発を進めている『日本 語歴史コーパス』は，奈良時代から明治・ 大正時代の広範な文献を納めているが，明 治・大正時代の小説は殁ど収録されていな い.このように，20世紀初期から近年まで の日本小説を収録し，公開した通時コーパ スは未だ見られない.

従って, 本研究はコーパス構築から着手 した. 山本（1965）によると, 現代書き言 葉の原型となる口語文体は，1909年までに 言文一致の確立期を終え, その後普及して きた [12]. そのため, 1910年から2014年ま での間に出版した小説を分析対象として 集めて，コーパスを作成した。一年ごとに 5〜6作品をサンプリングし，作家個人の文 体の影響を避けるため, 一人につき一作品 を使用することにした。作品を選定する際 に, 基本的には以下の2点を指標とし, その いずれかに該当するものを採用する。1つ はある時期の代表的な小説として文学選 集に収録されていること、『日本短篇文学 全集』(筑摩書房)，『現代日本文学全集』 (筑摩書房），『戦後短篇小説選』（岩波 書店）などの叢書を参考にした。もう1つは 芥川龍之介賞, 川端康成文学賞を始めとす る文学賞の受賞作品であること. 一方, こ の $2 つ の$ 指標で 1 年に5作品を集めにくい場 合があり，この時，芥川賞受賞作及び候補 作の掲載歴が多い文芸誌（『文學界』『群 像』など）から作品を選んで補足した。

コーパス構築にあたって, 青空文庫など の公開コーパス以外のものは紙媒体から 光学読み取り機器で電子化作業を行った. 
作成したコーパスには565名の作家の作品 が含まれている，今回の分析では，時代の 流れで見られる大きな傾向を掴むことを 主眼とするため，個人の作品における差を 考慮しないこととする.

テキストの長さのバランスを保つため, 5千字を目安に長さを統一する。つまり，5 千文字以下の短編小説は全文を使用し，5 千字を超えた場合, 5千字を目安として, 文 が完了するところまで切り取って用いた. この処理を行った結果, コーパスの作品の 文字数は3033〜 5132の間に収まった。対象 テキストに対し，括弧やダッシュなどの記 号で標記された会話文を削除し, 地の文を 分析の対象とした。

\section{2 助詞データの抽出}

コーパスに対し, 形態素解析を行い, 助 詞データを抽出する. 形態素解析器は $\mathrm{MeCab}$ 用いる. 形態素解析ための辞書は 何種類もあり，異なる特徽や利点を持つ [13]. 本稿では, 単語長と曖昧性解消との観 点から考慮し，デフォルトのIPA辞書を用 いた。 IPA辞書は学校文法をベースとして おり, 助詞が第2 層では格助詞, 係助詞, 副 助詞, 接続助詞, 終助詞, 並列助詞, 副詞 化助詞, 連体化助詞, 特殊助詞という9つの 種類に分類されている。本稿では第2層を 用いた。また，データを集計する際，「ヨ _格助詞」「を_格助詞」のような, 異表記 は同じ項目としてカウントした.一方，「た り_並列助詞」「だり_並列助詞」のような, 語彙の活用形の影響により清濁の違いが 生じる項目については, 異なる項目として カウントした。 その結果, コーパスから計 131項目の助詞が抽出された. 詳細項目を
付録に示す.

\section{3 分析}

助詞使用の歴史的変化を分析するに当 り，まず系統樹を用いて，変化が発生して いるかについて，その概観を示す。次に， その結果を踏まえて助詞のデータを説明 変数, 作品の初出年代を目的变数として, elastic net回帰モデルを構築し, 助詞使用状 況を回帰モデル化する。そして，モデリン グに大きく寄与する説明変数を見つけ出 し, 考察する.

\section{1 系統樹分析}

系統樹とは，言語や生物といった対象の 集合の要素に対して特徽量のベクトルを 抽出し，それを用いて，関連性を樹木の枝 分岐の形式に示したものである。系統樹の 生成手法は多く提案されており，距離行列 法がその代表的な一つである。距離行列法 とは，個体間の距離を何らかの形で定義し て，その距離行列を基に系統樹を推定する ことである。

距離行列に基づいた系統樹の生成法は 複数存在しているが, 本稿では最も広く利 用されている近隣結合法 (neighbor joining, NJ法）を利用する。近隣結合法は，距離行 列か複数の要素の近隣を段階的に見出し, 最終的に全ての要素が連結された系統樹 を得る方法である. 距離行列の計算につい て, 本稿ではJensen-Shannon Divergence (JSD) の平方根 $d_{R J S D}(\boldsymbol{x}, \boldsymbol{y})$ を用いる. その 式を式（1）に表わせる.

$d_{R J S D}(\boldsymbol{x}, \boldsymbol{y})=$

$$
\left\{\frac{1}{2} \sum_{i=1}^{n}\left(x_{i} \log \frac{2 x_{i}}{x_{i}+y_{i}}+y_{i} \log \frac{2 y_{i}}{x_{i}+y_{i}}\right)\right\}^{1 / 2}
$$




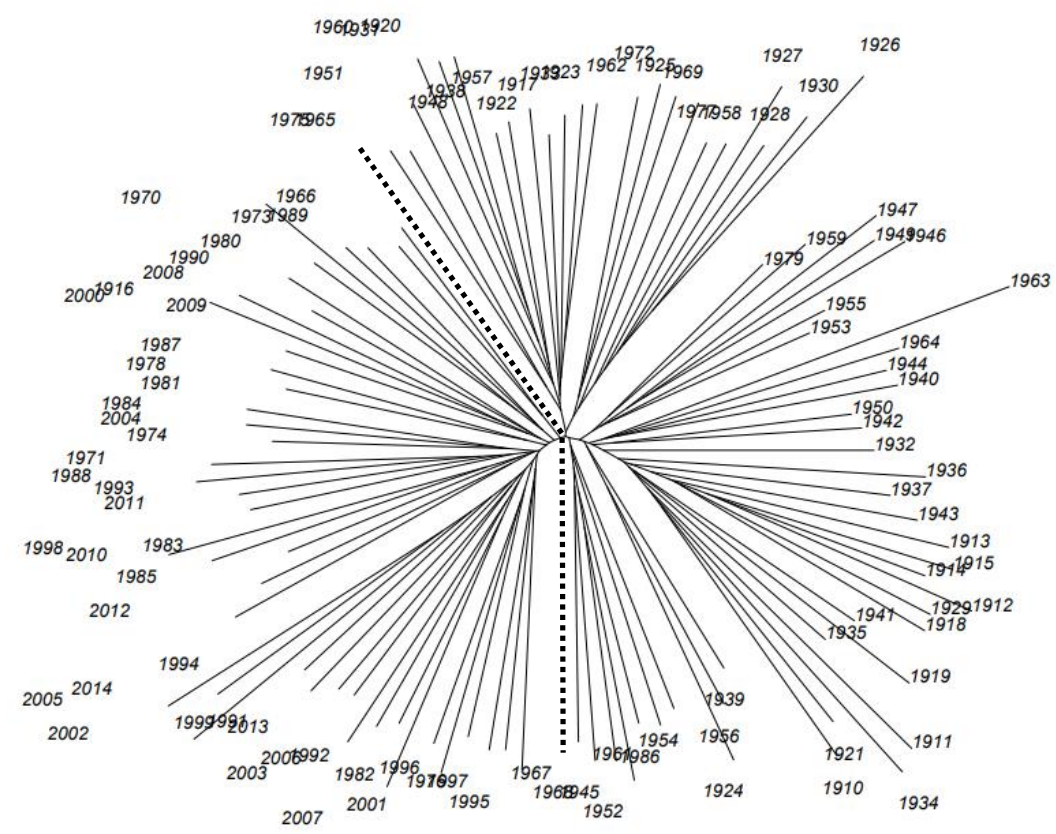

図 1 系統樹分析の結果（JSD 距離及び近隣結合法を利用）

表1 各年度の作品における助詞の百分率

\begin{tabular}{|c|c|c|c|c|}
\hline 年度 & $\begin{array}{l}\text { を/格助 } \\
\text { 詞 }\end{array}$ & $\begin{array}{l}\text { に/格助 } \\
\text { 詞 }\end{array}$ & $\begin{array}{c}\text { の/連体 } \\
\text { 化助詞 }\end{array}$ & $\cdots$ \\
\hline 1910 & 12.094 & 10.29 & 14.70 & $\cdots$ \\
\hline 1911 & 11.35 & 11.71 & 15.40 & $\cdots$ \\
\hline 1912 & 10.92 & 10.95 & 17.08 & $\cdots$ \\
\hline$\cdots$ & $\cdots$ & $\cdots$ & $\cdots$ & $\cdots$ \\
\hline 2013 & 10.36 & 11.43 & 14.70 & $\cdots$ \\
\hline 2014 & 9.83 & 11.54 & 15.40 & $\cdots$ \\
\hline
\end{tabular}

変化の状況を概観するため, コーパス内 の作品を初出年月に従い, 一年ごとに対象 小説をまとめて分析に用いる，そして，集 計した助詞の度数データを相対頻度に変 換する。データセットの百分率の形式を表 1 に示す.

図 1 に助詞の使用率のデータを用いた系 統樹分析の結果を示す. 図 1 の点線の右側 は 1960 年以前の作品が多く配置されてい るに対し，左側はほとんどが 1960 年以降 の作品である。これにより, 助詞の使用が 時期の推移に伴って変化している傾向が 窥える。

\section{2 elastic net回帰分析}

続いて，時系列情報と助詞使用状況を表 現する回帰モデルを構築し，モデリングに 寄与する特徽的な助詞項目を見つけだす.

回帰分析は，「現象の結果とそれに影響 をおよぼすと考えられる複数の要因と結 びつけるモデル」[14]である. 要因となる変 数を「説明変数」, 結果となる変数を「被 説明変数」とする，そして，説明変数が一 つの場合は単回帰分析, 説明変数が複数の 場合は「重回帰分析」と呼ぶ。重回帰分析 では，観測データを式（2）で表す．式の中 で， $x_{q}(\mathrm{q}=1,2,3, \cdots)$ は説明変数， $\beta_{0}$ は定 数項, $\beta_{q}$ は回帰係数, $\varepsilon$ は誤差項を表す.

$\mathcal{y}=\beta_{0}+\beta_{1} x_{1}+\beta_{2} x_{2}+\cdots+\beta_{q} x_{q}+\mathcal{E}(2)$

従来の回帰分析において, 残差の二乗和 の最小化, 又は尤度最大化によって回帰変 数を求める手法が適用されている。しかし なが，説明変数間に相関がある場合，過学 
習や多重共線性などの問題が起こりやす い. 諸問題の対策として，正則化などの方 法が提案されてきた. 正則化には, 変数選 択と次元削減を特徽とした L1 正則化, 係 数の縮小による過学習抑制を特徽とした L2 正則化がある.

本稿では，L1 正則化と L2 正則化を発展 させた elastic net 回帰を利用する. elastic net 回帰は，Zou and Hastie(2005)によって提唱 され, 以下の式（3）で与えられる [15].

\section{$\mathbf{L}(\boldsymbol{\beta})$}

$=\frac{1}{2} \sum_{i=1}^{n}\left(y_{i}-\beta X_{i}\right)^{2}+\lambda \sum_{j=1}^{p}\left\{\alpha \beta_{j}^{2}+(1-\alpha)\left|\beta_{j}\right|\right\}$

式の中の $\lambda$ は, 罰則の強さを調整するパラ メータである.入については, 交差検証 (10fold cross-validation）に基づき最適值を推定 する. 式の中の $\alpha(0 \leq \alpha \leq 1)$ は, L1 正則化 と L2 正則化の混合比率を調整するパラメ ータである。 $\alpha$ が 0 のときには ridge 回帰 （L2 正則化）となり， $\alpha$ が 1 のときには lasso 回帰（L1 正則化）となる. 本研究で は, 0 から 1 まで 0.1 刻みで変更し, 10 分 割交差確認を 1000 回繰り返し, 作成され たモデルについて AICの平均值を用いてモ デルを評価し， $\alpha$ を決めた。

回帰モデルを構築するため, 表1の助詞 データセットの右側に, 各年度の番号を表 す1〜105という数字列（ $y$ 列と呼ぶ）を目的 変数として付け加え, 131個の助詞項目を 説明変数とする.つまり，説明変数である 助詞項目を使って, 時系列を表す $y$ 列の目的 変数を説明できるモデルを作成する.

集計した助詞データを使って, elastic net 分析を行ったところ, 自由度調整済夕決定 係数が 0.97 あ゙あ回帰モデルが得られた。
また，その残差（絶対值）の四分位数はそ れぞれ0.06 (Min) , 1.67 (IQ) , 3.20 (Median)， 5.16 (3Q), 9.98 (Max) であり, 平均值 (Mean) は3.54である. 残差の最大值より, 推定誤差 が最も大きいものは約10年である.

elastic net回帰モデルでは8つの説明変数 が選ばれた。この8つの説明変数とその係 数を表 2 に示す。係数の絶対值が大きいほ ど回帰モデルでの影響が大きいと判断さ れる。

表2 elastic netに選ばれた説明変数の係数

\begin{tabular}{|l|l|}
\hline 1.の_格助詞 & -2349.24 \\
\hline 2.へ_格助詞 & -2294.87 \\
\hline 3.なんて_副助詞 & 1909.79 \\
\hline 4.で_格助詞 & 1097.08 \\
\hline 5.しか_係助詞 & 369.62 \\
\hline 6.さえ_係助詞 & -296.90 \\
\hline 7.が_格助詞 & 196.26 \\
\hline 8.よ_終助詞 & 87.81 \\
\hline
\end{tabular}

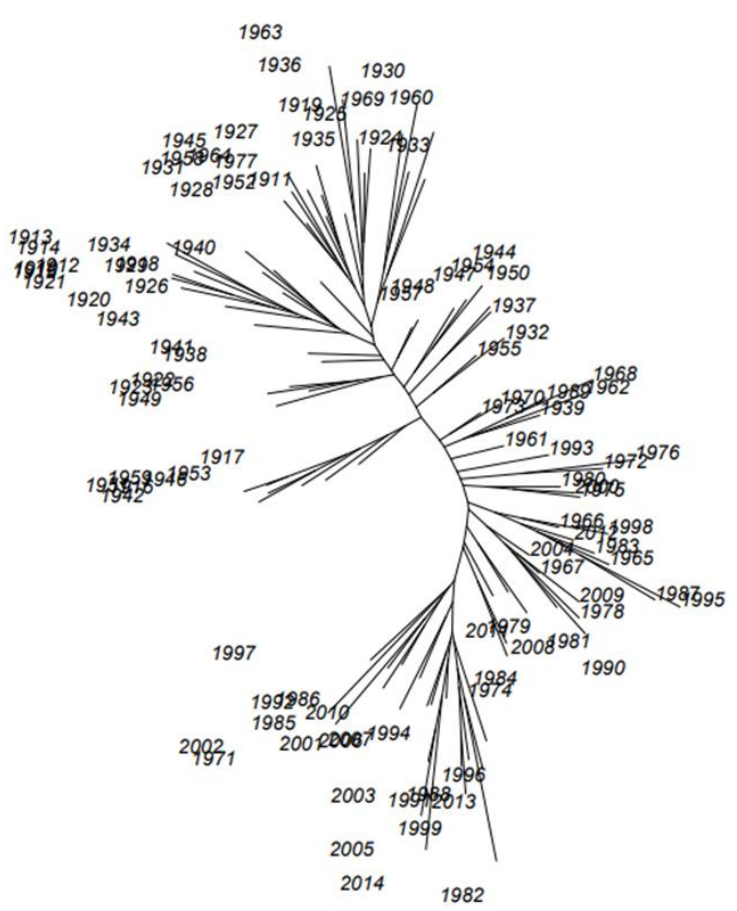

図2８つの助詞項目を用いた系統樹分析 

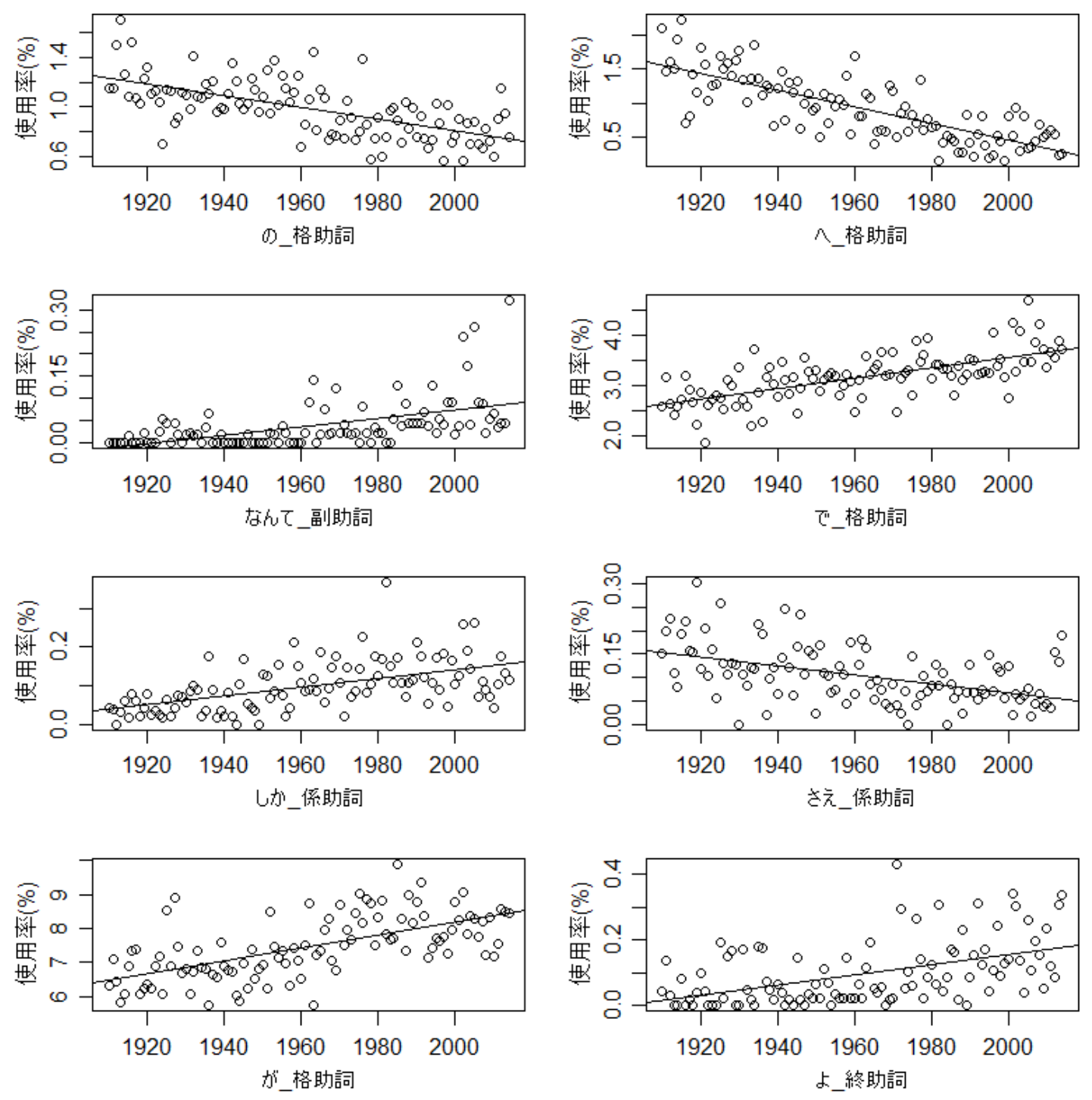

図3 8つの特徵的助詞の使用率の変化

elastic net回帰モデルで選択された8つの 助詞が近現代小説の言語表現の変化の大 まかな流れを反映できているかを確かめ るため，この8つの助詞の使用率を用いて， 改めて系統樹分析を行い, その結果を図2 に示す。

図2からみると，全体的には，上から下の 方向へ，大まかに時期の流れが読み取られ

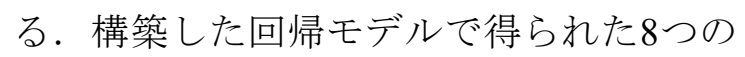
助詞について，それぞれの使用率に回帰直 線を加えたプロットを図3に示す.プロッ
トより，「の_格助詞」「人_格助詞」「さ え_係助詞」が右肩下がりで減り続けてお り，「なんて_副助詞」「で_格助詞」「し か_係助詞」「が_格助詞」「よ_終助詞」が 時期の推移に伴い増加の傾向を示してい る.

作成されたelastic netモデルを確認するた め, 非線形的関数を用いたランダムフォレ スト（random forest, RF）によるモデルを 構築し, 選択された重要度が高い変数で対 照する. ランダムフォレストの詳細に関し 
ては, 金 (2021) の解説を参照されたい [16]. RFによって選択された上位 15 個の変数の ドットプロットを図4に示す。この15個の 変数には， elastic netモデルで選出したもの が全て含まれている。また，図4から分かる ように，第10位から小さい值に収束してい る.上位の10個まで共通しているのは，「へ _格助詞」「が_格助詞」「の_格助詞」「で _格助詞」「なんて_副助詞」「しか_係助詞」

「よ_終助詞」であり, 高い一致度を示して いる.

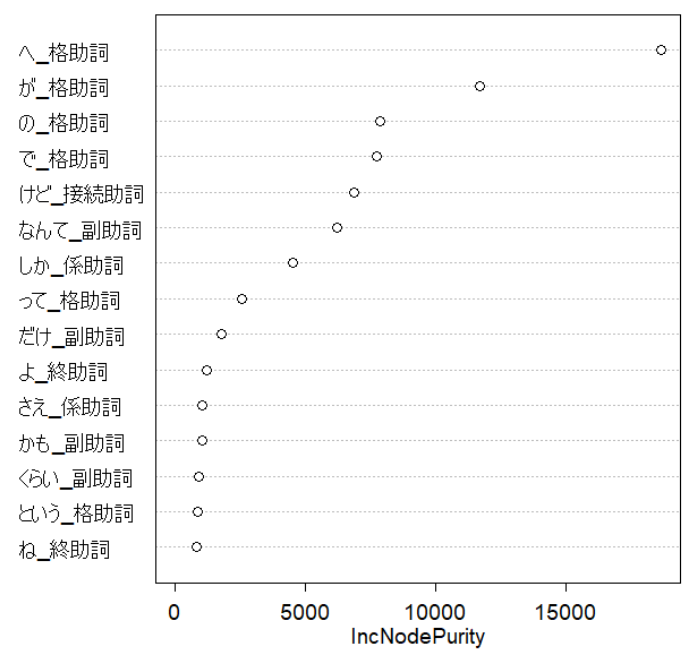

図4 ランダムフォレストによる変数の重要度

\section{4 考察}

elastic net回帰モデルで選択された特徵的 助詞項目には，格助詞「へ」「で」などの ような, 意味（語義）が多様であり出現頻 度が高いものもあれば，語義の種類が比較 的に少なくそれほど頻繁には使われてい ないものもある，その変化は何を意味して いるか，或いは文章の表現様式・文体にど のような影響をもたらしているかについ て, 助詞ごとの特性に応じて考察を進める 必要がある。
語義も数も多い助詞に対し, 周囲の語彙 との関係を糸口にして, 変化の詳細及びそ れが言語様式・文体との関りを浮き彫りに することが可能である. その方法の一つと

して, 共起ネットワークを通して対象助詞 とその前後の語彙との関りから考察する ことが挙げられる。一方, 出現頻度が低い ものに関して，一文一文確認して考察する ことができる.

\section{1 格助詞}

この節では，格助詞「へ」を始めとする 出現頻度の高い格助詞を例にとり, 対象助 詞を含む語彙のbigram（助詞と一つ前/後の 語彙による組合せ）を用いた共起ネットワ ーク分析を行う。

\subsection{1 格助詞「へ」}

比較対照で変化を捉えるため, コーパス 内の最初の10年間（1910～1919）及び最後 の10年間（2005～2014）のデータから，格 助詞「へ」及びそれと共起する語彙項目を bigramの形式で抽出して分析を行う. 出現 頻度が5以上の共起項目を用いて，「へ」を 頂点としたネットワークを描く。語と語を 結ぶ矢印は, 関係の方向性を示し, 文章で 現れる順序を示す. 点線に付与された数字 は，共起組合せの出現頻度であり，結びつ きの相対的な強さを示す.

1910～1919年及び2005～2014年という 二つの区間の分析結果を図5，6に示す。困 5,6 からみると, 格助詞「へ」の出現頻度 が減少するにつれ，格助詞「へ」に関わる bigram項目が大幅に減っている. 寸べての bigram項目において「名詞十へ」及び「へ+ 動詞」といった共起が多数であるため, そ の減少は特に顕著に見える. 動詞に着目す ると, 図5より「落ちる」「置く」「出す」 


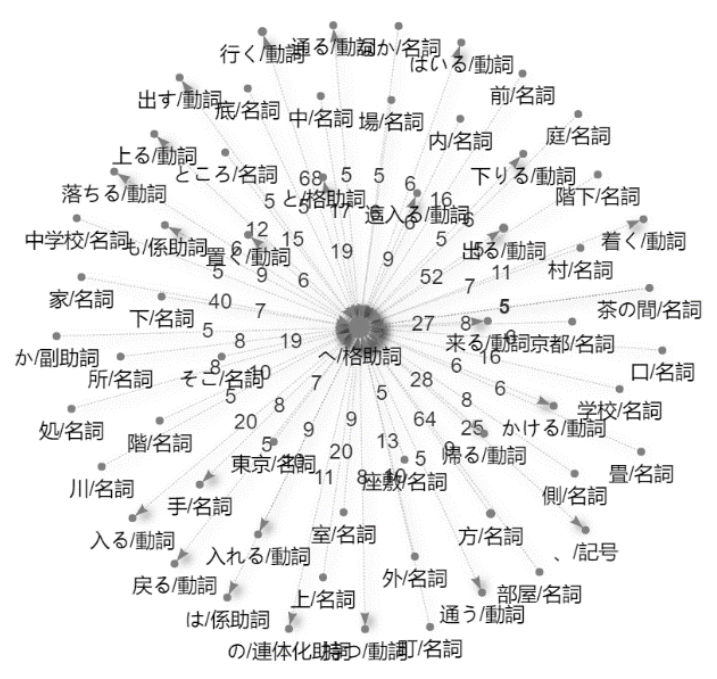

図5 頂点格助詞「へ」のネットワークグラフ

（1910 1919年）

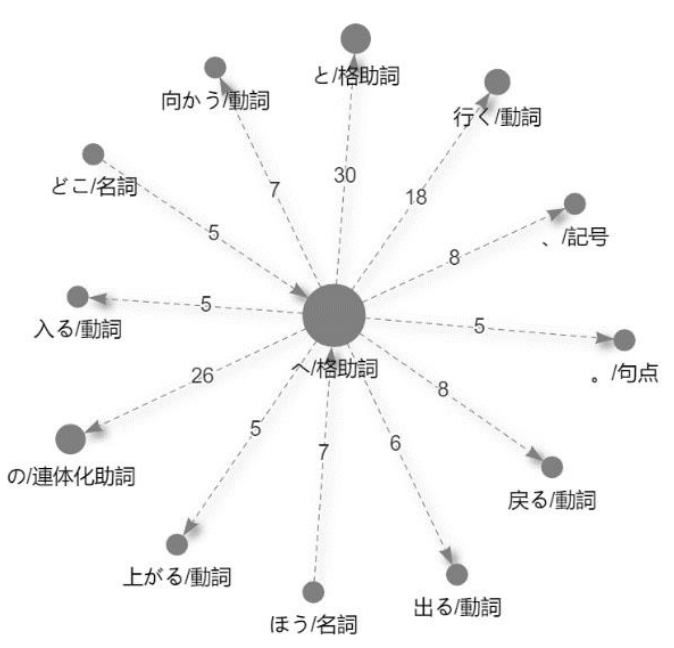

図6 頂点格助詞「へ」のネットワークグラフ

（2005 2014年）

「入れる」「着く」「かける」など，<着 点>を表す動詞との共起は多く見られる が，図6ではほとんど見られない。それに 対し，「行く」「戻る」「入る」「出る」

「向かう」などのような，＜方向＞を表す 動詞は, 図 5 と図 6 の両方に現れている. 現在の言語感覚からみると, <方向 >を表 す動詞と共起する「へ」は，その多くが格 助詞「に」で代用することができ，格助詞
「に」のほうがより自然に聞こえる場合も ある.コーパス内の 1915 年の作品におけ る一文を例として挙げる.

例（1）こうして夜明けになって電灯を 消すと，小川と云う電気職工は或る遠い 下町の学校二通っている為め大急ぎで帰 って行く. 機関手の沢井と俊治だけ後へ 残って機械の掃除やら日誌の記入やらを 済ませてから，瓦斯機関の汽筒から湧い たお湯で風呂へ這入る。（1915 年）

「学校へ通っている」「後へ残って」「風 呂へ這入る」などの類の「へ」は時期の推 移につれ，「に」に取って代わられてきた 可能性があると考えらえる。一方，格助詞 「へ」と「に」に対し，相対頻度データ（デ 一タの形式は表1を参照）のピアソン相関 係数を確認した結果, $-0.42 か ゙$ 得られ, 弱い 負の相関が存在すると判断される。この点 からみると, 格助詞「へ」の使用変化につ いて，格助詞「に」との間の勢力消長・役 割分担による影響が否めないが，す心゙て格 助詞「に」の代用に帰するものではないと 推察する.

図5にも図6にも存在する項目として, $\lceil$ 「の_連体化助詞」「へ+と_格助詞」 $\lceil へ+，$ 読点」がある。前の二つは，それ ぞれ「への十名詞」「へと十動詞」に等し い項目であり，その中の「へ」は，ほかの 助詞によって代替されにくいと考えられ る.

一方，図5にはなかったが，図6には現 れた項目として，「へ+。_句点」が見ら れた，使われたコーパスを確認したとこ ろ, 述語を省略して, 格助詞「へ」で終 える文は，1966年以前の作品に全くな 
く, コーパスの後半に存在している. そ うした表現は，新聞記事の見出しや広告 ヘッドラインなどによく使われると指摘 されているが[17], 最近になって小説にも 使われるようになったことが今回の分析 で明らかになった。その数はまだ多くは ないが，述語の省略により文内に余白・ 余韻が残されたり，文末表現に変化がも たらされたりするような効果がある.

例（2）紙川さんは神奈川県横浜市二. 私は埼玉県さいたま市二．（2009年）

例（3）洗濯を終えて，公園へ. 砂場の 前にしやがむ，美和さんの背中が見え た.（2010年）

\section{1 .2 格助詞「で」「」「が」}

格助詞「で」「の」「が」に対し, 同じ く最初の10年間（1910～1919）及び最後の 10年間（2005～2014）におけるbigram項目 をネットワークで分析した。

二つの区間を比較した結果, 格助詞「で」 において，場所を表す名詞との共起が増え ていることが確認された。「場」が明確に 提示されることによって「コト的体験的把 握」がよりしやすくなると尾野（2018）は 述べている [18]. つまり, より知覚的・感 覚的に捉えやすくなり，そのことによって， 「共感」の度合いが高まるのである。でき ごとの起きる場所や動きの空間範囲を明 示することによって, 読者に物語の内容を より感覚的に捉えさせ，共感を呼びやすく する効果が見込まれる。「で」格の増加に は，空間変換による遠近感を現出させたり， 読者に現実感覚を与えたりするような作 家達の表現意識が働いていると推測され る.
一方，格助詞「の」「が」について，市 ットワーク分析により，二つとも主に「名 詞」の後,「動詞」「形容詞」の前に現れ ており，この使用傾向が変わっていないが， 格助詞「の」は減少し，「が」は増えてい ることが確認された。『広辞苑』によると， 述語の表す内容をもたらした主体につい て，主文で「が」を使うのに対し従属文で は「の」を使うとする考えもあったが，現 代語では，従属文でも「が」で表すことが 多い [19］。今回の結果はこの点を裏付け ている，とはいえ，格助詞「が」の増加量 は格助詞「の」の減少量を大きく上回るこ とが見逃せない.

「が」文型の多くは，話し手自身の目に 映り心に感じた事柄を直接に述べる現象 文である。「が」格の現象文は，「極めて 自己中心的で場面依存型の表現形式」 [20] と指摘されているが，逆にいうと読み手に 話し手の視点に立たせ, 臨場感のある叙述 に連れて行く効果がある，格助詞「が」の 増加は, 話者の心の内や目に映る情景をそ のまま綴るという表現が増えていること を示唆している.

\section{2 そのほかの助詞}

格助詞に比べ，同じく特徵的項目である 副助詞「なんて」, 係助詞「しか」, 「さ え」及び終助詞「よ」は出現頻度が相対的 に少なく, 語彙内における語義差異もそれ ほど大きくない。 これらの項目に対して, 使用された文を確認した。本稿では, 紙数 の関係から全ての解説を記すことができ ないが，一二例の説明を簡略的に提示する。

係助詞「しか」は使用率が上がる傾向を 示している.「しか」は，「花子しかいな い」のように否定述語と拘束関係を持って 
いる.この「しか」の拘束関係が出現した のは近世初期以降であることが指摘され ている[21]. そして,「しか」の類の助詞の 成立は, 否定表現の変革に大きく関わって おり，その本質は日本語述語構造そのもの の歴史的変革との指摘もある[22].「しか」 を始めとする否定呼応表現は, 既に研究者 に注目されていたが，質的，記述的に言及 されるにとどまっていた. 今回の分析結果 は, 先行研究の見解の定量的裏付けになる と同時に, その意義を改めて認識し, 再評 価するための契機ともなりうる.

終助詞「よ」も時期の推移に伴って増加 している.コーパスを確認したところ，「よ」 のみではなく, 終助詞の全体使用率は2000 年前後に増えてくる傾向を示した. コーパ スクリーニングの際, 括弧やダッシュなど の記号で標記された会話文を削除したた め, 使われたコーパスにおける終助詞は, 括弧などの記号が付けられない引用文, 又 は独話や心内発話文などに現れることが 多い.「よ」を始めとする終助詞の増加は, 内的モノローグの叙法やくだけた言葉遣 い，喋り口調という特徵を持つ小説が多く なっていることを示唆している. その原因 について深く検討する余地があるが，イン ターネットの普及に相まって発達してき たブログなど新メディアの表現による影 響の可能性が考えられる.

\section{5 まとめ}

本稿では, 近現代小説コーパスを構築し, それをもとに, 助詞の経時変化を捉えると 同時に, 特徵的な変化項目を見出して, 文 章の表現特性・文体様式との関わりを考察 した. 系統樹分析により, 1910 年から 2014 年までの百余年の期間において, 助詞の使
用に明らかな時系列経時的に変化が発生 していることが分かった. elastic net 回帰分 析を通して，格助詞の「の」「へ」「で」 「が」, 副助詞の「なんて」, 係助詞の「し か」「さえ」及び終助詞の「よ」が特徴的 項目として特定された。見出された特徽的 助詞項目から, 語学や文体学の研究のヒン トとなりえる可能性が示唆された。

一方, 本研究では回帰モデルを応用して 考察を進めていたが，実際の様態ははるか に複雑である可能性は否定できない。その 実態にさらに近づくため, 複数の手法を組 み合わせ，比較しつつより効果が良いモデ ルを構築することが必要である。また，助 詞の出現頻度データを元にモデルを構築 したが，出現頻度は特に増減していないに も関わらず，係り受け語が変化したパター ンが存在する可能性がある。このような変 化を視野に入れて考察することも検討に 值する.ささらに, 時期の区切りの設定調整 や，会話文の追加などにより，結果に違い が生じるかどうかに関して，比較検証を行 うことが必要と考えられる。いずれも今後 の課題として取り組んでいきたい.

\section{謝辞}

本研究の一部は科研費（課題番号： 18K00627）の助成を受けて行われたもので ある、本研究をご支援下さった同志社大学 文化情報学研究科のデータサイエンス研 究室の皆様, 有益なコメントを下さった匿 名の査読者に深謝致します.

\section{参考文献}

[1] 森田良行：『助詞・助動詞の辞典』, 東 
京堂, 18 p., 2007.

[2] 山口明穂：「尚古・擬古意識と文体史 のその反映」，『講座日本語学 7 文 体史 I』, 明治書院, pp.246-264, 1982.

[3] 柳父章:『近代日本語の思想一翻訳文体 成立事情』法政大学出版局, 2004 .

[4] 時枝誠紀：「国語に於ける変の現象につ いて」, 国語学, Vol. 2, pp.1-16, 1949.

[5] 水谷静夫 : 「戦後小説での格結合型」, 計量国語学, Vol.21, No.8, pp.345-360, 1999.

[6] 荻野孝野:「日本語動詞の結合価の格助 詞パターンと意味マーカに関する研 究」, 神戸大学大学院自然科学研究科 博士論文， 2006 .

[7] 石川慎一郎:「現代日本語における『デ』 格の意味役割の再考一コーパス頻度 調査に基づく用法記述の精密化と認 知的意味拡張モデルの検証一」, 計量 国語学, Vol.31, No.2, pp.99-115, 2017.

[8] 中西久美子 :「書きことば・話しことば のコーパスにおけるとりたて助詞の 使用の実態」, 京都外国語大学研究論 叢, Vol.69, pp.171-185, 2007.

[9] 宮内佐夜香：「接続助詞とジャンル別文 体的特徵の関連について一『現代日本 語書き言葉均コーパス』を資料として 一」, 国立国語研究所論集, Vol.3, pp.3952, 2012 .

[10] 丸山直子 : 「コーパスにおける格助詞 の使用実態：BCCWJ・CSJ にみる分 布」, 計量国語学, Vol.30, No.3, pp.127$145,2015$.

[11] 小林雄一郎; 小木曽智信:「中古和文に おける個人文体とジャンル文体：多
変量解析による歴史的資料の文体研 究」, 国立国語研究所論集, Vol.6, pp.2943, 2013.

[12] 山本正秀: 『近代文体発生の史的研究』, 岩波書店，1965.

[13] 工藤拓 :『形態素解析の理論と実装』, 近代科学社, 2018 .

[14] 小西貞則：『多変量解析入門——線形 から非線形へ』第 7 刷, 岩波書店, 2 p., 2019.

[15] Zou H, Hastie T. : "Regularization and Variable Selection via the Elastic Net", J R Statist Soc B., Vol.67, No.2, pp.301$320,2005$.

[16] 金明哲：『テキストアナリティクスの 基礎と実践』，岩波書店，2021。

[17] 李欣怡：「格助詞で終わる広告ヘッド ラインに隠されたもの：文の『述べ方』 という視点から」, ことばの科学, Vol.15, pp.5-22, 2002.

[18] 尾野治彦：『「視点」の違いから見る日 英語の表現と文化の比較』, 開拓社, 2018.

[19] 新村出（編）:『広辞苑』第 7 版, 岩波 書店, 2275p., 2018.

[20］森田良行：『日本語の視点—ことば を創る日本人の発想』第 4 刷, 創拓社, $54 \mathrm{p} ., 1998$.

[21］山口堯二：「副詞『しか』の源流— その他を否定する表現法の広がり」, 日本語語源探求委員会『語源探求 3』, 明治書院, pp. 34-48, 1991.

[22] 宮地朝子：『日本語助詞シ力に関わる 構文構造史的研究：文法史構築の一 試論』, ひつじ書房, 2007. （2021年 5月 21日 J-STAGE早期公開） 
付録 コーパスより抽出された助詞項目

\begin{tabular}{|c|c|}
\hline 格助詞 & 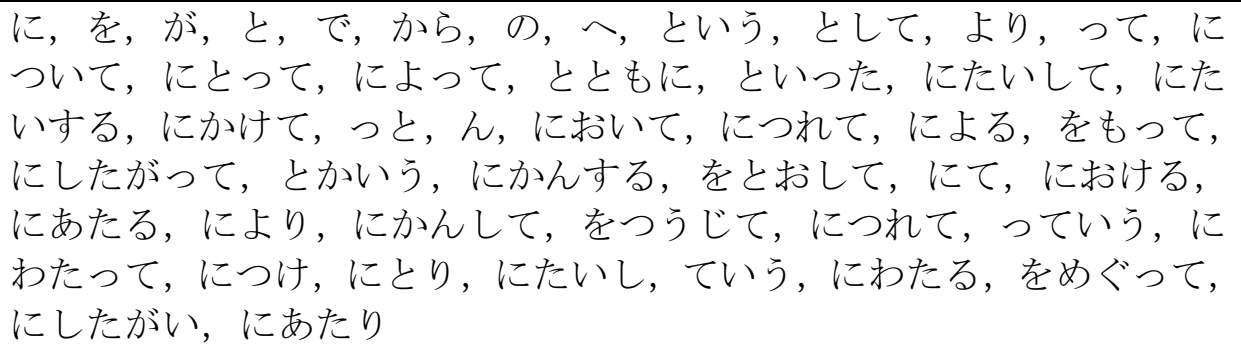 \\
\hline 係助詞 & は，も，さえ，しか，こそ，すら，や，ぞ \\
\hline 副助詞 & $\begin{array}{l}\text { まで, だけ, ほど, など, でも, ばかり, かも, くらい, じゃ, ぐら } \\
\text { い, とも, なんて, ずっ, だって, のみ, なんか, なぞ, なり, し } \\
\text { も, なんぞ, やら, ばっかり, だに }\end{array}$ \\
\hline 接続助詞 & $\begin{array}{l}\text { と, が，て，で，ながら，ば，から，ので，のに，し，けれども，け } \\
\text { れど，けど，つつ，とも，ものの，ちゃ，なり，どころか，や，たつ } \\
\text { て，じゃ，からには }\end{array}$ \\
\hline 終助詞 & $\begin{array}{l}\text { か, な, よ, ね, お, の, け, べ, さ, ぞ, なあ, かしら, やら, ね } \\
\text { え, ぜ, かい, ねん, っけ, や }\end{array}$ \\
\hline 並列助詞 & と, や, たり, だり, とか, やら, だの \\
\hline 副詞化助詞 & に, と \\
\hline 連体化助詞 & の \\
\hline 特殊助詞 & に \\
\hline
\end{tabular}

